\title{
12 Community-based sponsorship of refugees resettling in the UK
}

\author{
British values in action?
}

\author{
Joanne van Selm
}

\section{Introduction}

The United Kingdom has a centuries long history of welcoming refugees and migrants to its shores. While there is, and always has been, some degree of citizen opposition or reluctance towards the arrival of newcomers, the UK also has a wide base of civil support for newcomers. This has sometimes been vocal, for example, in the case of Kosovars in 1999, when, as in other EU Member States, outspoken popular support for the displaced population prompted governments to instigate a Humanitarian Evacuation Program, for the organized movement, and temporary protection, of over 54,000 people, of whom 4,346 were welcomed to the UK (Guild 2000: 67). The baseline norms and values on which UK immigration and asylum law and policy are based are, in essence, humanitarian but they are also contested.

Encapsulating 'British values' and applying them to the migration field is a significant challenge. It probably always was so, but in 2019, as Brexit hangs in the balance and British politics seems to spiral out of control, it is even more challenging. Part of the confusion or complexity is in the very essence of what it means to be 'British.' Add to that the muddle of what exactly are 'British values' and then how these are expressed in relation to immigration and refugee protection and the complexities are compounded. Yet, at the heart of any discussion about 'values,' it could be said, there is a point to be made about compassion and tolerance - about tolerating and being tolerated.

While passions rage about immigrants and the lack of integration, a relatively small, but growing, group of British citizens is putting compassion and tolerance into practice through their support and sponsorship of refugee resettlement. Conceptually, this practice of sponsorship of these newcomers could be seen as an island of calm amidst very troubled waters: the refugees being selected, who have fled the conflict in Syria, are avoiding the dangerous sea crossings being undertaken by asylum seekers in the Mediterranean and participating in an exemplary scheme of orderly arrivals. The sponsors stand out from the crowd of anti-immigrant voices, as they have pushed for, and now put into practice, the ability to support refugees in their gradual 
finding of their place in British society. Whether or not we can really establish agreement about what 'British values' are, tolerance is fundamental to any society in which there are differences - and there is no society without differences.

The core questions for this chapter will be: how can we conceptualize participation in community sponsorship efforts from a values perspective? How could sponsorship of refugees by a few spread those values to, or strengthen those values in others in society? How can tolerance be understood, and developed, in a country where immigration has happened more quickly than its core citizenry has managed to adapt to it?

The chapter will first draw the broad outlines of the discussion of, and what can be understood by, 'British values.' By way of background, it will then turn to the re-emergence of resettlement as an avenue to protect refugees in the UK, and how the community sponsorship program came about, as a response to requests by some civil society organizations. The community sponsorship scheme aims at facilitating the integration, through various support mechanisms, of some of these refugees. Based on secondary research, the Community Sponsorship Program and its implementation will then be described. Evaluations of the program conducted to date will be drawn on to examine specifically how it is faring as an expression of British values, both through the integration of refugees, and through the avenue it presents to sponsors to strongly uphold the value of tolerance, while intolerance seems to hold sway in parts of the population around them. The program, and its place in the British value system, will then be analyzed from the perspective of toleration, based on the essays of that name by Michael Walzer (1997) including the expansion of toleration and its limits. This chapter is primarily a 'think piece,' consisting of desk research and the pondering of the somewhat theoretical extent of toleration in a constantly evolving community and society.

\section{What are British values?}

In the first two decades of the twenty-first century, faced with domestic and international terrorism and extremism, the UK has set about searching for a national identity. The coalition Conservative-Liberal Democrat government in power from 2010 to 2015 determined a set of British values, in the context of the prevention of extremism, and decided that these should be taught in schools and implemented in various public settings. This decision to define 'British values' came after centuries of essential muddle, in which what it meant to be 'British' or to hold 'British values' was not defined, but was fairly clear to everyone in an unspoken way (Richardson 2015). Having drafted a set of 'British values' and started trying to spread them, the government and population find that they are intrinsically contested, and may not be making the situation any better or clearer. In relation to immigration and refugee protection this becomes even more the case, as terms such 
as 'humanitarian' and 'tolerant' are used, but not always lived up to in the eyes of many - or overdone in the eyes of others (see Jarvis, Atakav, \& Mardsen 2017).

The 'values' debate in the UK is extremely complex at this point in time, not least because both the 'values' and their representation as 'British' are entwined in the near even split in the country over not only EU membership, but what Britain, as part of broader Europe, means: Britain in the EU is more clearly outward looking, accepting of diversity and tolerant. Britain leaving the EU is less tolerant, less accepting of diversity, inward looking, and may ultimately fully devolve into a disunited former kingdom.

As such, it is difficult, perhaps impossible, to point to facts on what British 'values' are: people on different sides can say they hold the same things to be their guiding norms, yet mean something completely different from each other.

The British anti-immigration nationalists claim to wish to protect a proud country, that stands tall, alone as a strong nation. Indeed, a Google search of 'Nigel Farage British Values' brings a stream of two types of articles to the fore. The first are interviews and supporters' opinion pieces in which the Brexit/ex-UKIP leader is cited as the champion of 'British values' who will protect the Judeo-Christian culture, national identity, and allow people to 'be British' again. The second category are an equal number of commentary articles strongly asserting that Farage/UKIP/Brexit Party stand for the precise opposite of real British values and above all are stoking racism and intolerance. Describing, very soon after the 2016 referendum, how the notion of British values has been discredited and become muddled, Yates points out that:

While incidents of racism are on the rise, perhaps it is the insidious racism normalized through political rhetoric that has ignited racist attitudes to boiling point. The seemingly single narrative of the Leave campaign was effective because it aligned with attitudes that politicians across Labor, Conservative, and UKIP have been rolling out since last year: that the so-called 'British Values' - of liberty, independence and strength - have been squashed by new immigrant populations who have muddied the waters of British Values. The referendum result provided the catalyst for attitudes towards immigrants to come to a head.

(Yates 2016)

This focus on what is meant by British Values has, as noted, been a major topic for the British government, sparked by discussion arising from acts of Islamic terrorism in the UK, starting with the July 2007 attacks in London. The coalition government of 2010-2015 sought (perhaps understandably in the political climate, but perhaps also leaving margins for misinterpretation and misunderstandings) to deepen the sense of values through teaching in school as well as the approach to national security. 
The UK government's Office for Standards in Education, Children's Services and Skills (Ofsted) requires that British values be taught in schools across the country. These values are: democracy, the rule of law, individual liberty, and mutual respect for and tolerance of those with different faiths and beliefs and for those without faith.

This list of British values is taken by Ofsted from the 2011 UK Home Office report Prevent Strategy designed to update the government's approach to terrorism and extremism (UK Government 2011). While this is the definition of British values included in the report's Glossary, elsewhere the report refers to British values as: 'democracy, rule of law, equality of opportunity, freedom of speech and the rights of all men and women to live free from persecution of any kind' (UK Government 2011: 44). In other words, even the original governmental source on the defining of 'British values' gives at least two definitions.

Some parts, and sometimes large parts, of the UK population have serious reservations about a multi-cultural and really diverse approach to those arriving and their integration. This is not new. Opposition to immigration was notoriously espoused by Enoch Powell, with his Rivers of Blood speech in 1968. The immigration of that time was primarily from the Commonwealth, and the grounds for opposing it were above all racial. The British nationalists of the late 2010s, emboldened by the 2016 referendum outcome for the UK to leave the European Union, 60 years on from Powell's (deliberately) inflammatory vision, indicate they would return to a focus on the Commonwealth, not for immigration necessarily, but for trade and international alliances, and oppose both European and non-Christian, in particular Muslim, immigration. A 2018 British Futures report looking at the 50 years since Powell's speech addressed the evolving nature of British society's position on immigration, race and diversity, showing how Powell was wrong, and that Britain has largely avoided the racial strife foretold, although the country faces continued, if different, challenges on the immigration and integration front (Ballinger 2018).

Nonetheless, the value those opposing immigration apparently contest is that of equality and of 'mutual respect for and tolerance of those with different faiths and beliefs and for those without faith.' This is crucial to a consideration of British norms and values in relation to immigration and migrants today. While the drafting of this 'value' might have come about in the context of, essentially, explaining to immigrants what they are expected to do to integrate in and be part of British community, the problem it exposes is that a large part of the British community has limited or no tolerance for people with different faiths and beliefs, particularly if their faith is (or is thought to be) Islam.

The think tank British Future together with the group HOPE not hate conducted a National Conversation on Immigration involving 60 meetings across the UK as well as online surveys culminating in a June 2018 final report (Rutter et al. 2018). It found that 75 percent of both UK born and 
non- $\mathrm{UK}$ born respondents saw integration as showing respect for British traditions and values (p. 123), and that those responding were roughly equally split on the question of whether or not migrants integrate in their local communities (p. 125). Indeed, people who had migrated to the UK in the 1950 s, for example, suggested that their approach to integration at that time was significantly different from that of today's newcomers (p. 213): it is not clear, as the context that inspired Powell's 1968 speech shows, that British citizens of the day agreed. A minority of respondents to the National Conversation on Immigration saw the responsibility for adaption as being only on the shoulders of the immigrants, with a majority seeing a question of respect for shared values being a responsibility of all involved, including government as well as the broader population (p. 129). Shared values as a basis for integration were perceived as the third most significant factor, slightly behind newcomers learning English and contributing through taxes and employment to British economy and society (p. 130). At the same time, respect for refugee protection was viewed as being intrinsic to British values (p. 153).

There are two primary groups of immigrants who face intolerance in the UK in 2019: Europeans who have migrated under freedom of movement regulations of the EU and people who are, or sometimes are presumed to be although they are not, Muslims. These two 'groups' (although neither is homogeneous) are vastly different both in the resources they bring to their movement, and the options they have, as well as in what their 'integration' means. The EU citizens generally have more resources, if not always necessarily in monetary terms then in services they can access. They have many more options, not least because they can choose to live in another 27 different countries, without legal impediment, although they may have made their family, economic, and cultural life in the UK for many years. Their integration is also different in that they are equal EU citizens, and have been in every way until the challenges and unforeseen barriers thrown up by the impending and unresolved issues of Brexit emerged.

The main target of the right in opposing Muslim (or thought to be Muslim) entry, protection, and integration are refugees, particularly from the Middle East, although also from Afghanistan and countries in Africa. Syrians, and other Arab and/or Muslim citizens displaced by the conflict in Syria constitute a major proportion of this group. These refugees generally have fewer resources available to them, from financial and language, to the presence of or ease in visiting family, for example. Starting a new life, often leaving the remnants of their former selves behind in refugee camps, the integration of these refugees can naturally be expected to be a challenge. That is the case even in a society that has invited the refugees in through a resettlement program.

The increasingly vocal, populist and extremist opinions which have entered the mainstream of British politics and public life have been emboldened by the outcome of the June 2016 Brexit referendum, and relative success of nationalist parties as well as the more right-leaning part of the 
governing Conservative party. There is, of course, statistically not a great margin of difference between the 52 percent for leaving the EU and the 48 percent for remaining in it, and another referendum could well return a quite different result. This close political division is reflected in the approach to immigration: some opinion surveys suggest that the UK population is fairly evenly split between people who wish to see current levels of immigration maintained or increased, and those who want some level of cuts in immigration numbers (Blinder and Richards 2018). While these latter voices frequently suggest that immigration challenges British values as refugees and immigrants sometimes find it difficult to integrate for various reasons, it can also be reasonably argued that those opposing immigration and establishing barriers to integration are themselves an affront to British values, and in particular that of tolerance. In other words, the challenge to British values comes not necessarily from newcomers, but from those in British society who reject refugees and those of 'other' or 'no' faith, of other ethnicity, of other nationality, and of other world view.

While some vocal elements across British society and the political realm speak about their British values and against those of other faiths (specifically Muslim), other parts of civil society in the UK are quite quietly, but strongly, supporting diversity, freedom from persecution and fear, and assisting newly arrived refugees very directly. In so doing, they are also supporting the British government in putting into practice the values for which it says it stands, even as some politicians of the governing Conservative Party seem to undermine those values in parliamentary and public debate. Civil society organizations sponsoring refugees fleeing conflict in Syria and arriving on the UK's resettlement program support not only the newcomers but also, it could be argued, the very essence of British values.

\section{Background: revival of resettlement and establishing sponsorship}

The vast majority of refugees arriving in the UK, as in most of Europe, at least since the 1970 s, enter the country requesting asylum or request asylum as an extension of their (regular or irregular) stay. In the past 15 years, European countries have looked more closely at alternative, and particularly organized, means of arrival for refugees. Primary amongst these has been resettlement - one of the three durable solutions for refugees, involving selection in a country of first asylum, preparation for and actual travel, arrival, with legal immigration status and integration support. Other more recent methods of such organized arrival programs include various Complementary Pathways, such as Humanitarian Admission Programs, Private Sponsorship, student visas and scholarships and labor mobility programs (ERN+ 2017; ERN+ 2018).

At the time of the 1999 Kosovar Humanitarian Evacuation Program mentioned above, the UK had only an extremely limited resettlement program, 
for just ten refugees requiring medical treatment each year. Organizing the arrival of 4,346 Kosovar gave a taste of how a larger resettlement program could work, even if they were being evacuated for temporary protection in that specific context. In 2004, the UK embarked on a broader resettlement program, The Gateway Protection Program, with a quota of around 750 arrivals per year (UK Government 2016a). The Gateway Protection Program has remained at a consistent level in its fifteen years of operation to the time of writing and welcomed refugees from a range of countries, offering them support in their arrival in the UK and their endeavors to integrate (e.g.; Collyer et al. 2019). In addition, the UK created two programs specifically for the resettlement of Syrians. The Vulnerable Persons Resettlement Scheme (VPRS), initially announced in 2014 as a plan to resettle several hundred Syrians over three years, but re-launched in September 2015 to accept 20,000 Syrians, and altered again in 2017 to accept refugees who have fled conflict in Syria but do not necessarily have Syrian nationality (UK Government 2017). The Vulnerable Children's Resettlement Scheme (VCRS) announced in 2016 was intended to resettle up to 3,000 children from the MENA region over approximately a three-year period (UK Government 2016b). In June 2019, the UK Government announced the intention to combine the programs from 2020 onwards, into one global program, with 5,000 refugees to arrive under the government's provisions and an additional number of refugees who would be sponsored by community groups (UK Government 2019).

The resettlement schemes allow for the expression of British values, as is the case for other resettlement countries, through open advocacy for support to specific refugee groups considered à priori to be in need of protection. Some critics might say that resettlement gives governments (and their countries) the opportunity to suggest they are 'doing something' while actually pursuing policies that limit refugee and migrant arrivals under cover of these 'open' approaches. In a similar way, support for countries in the regions of origins of displacement while doing little to develop greater capacity to accept migration and refugee protection at home, is criticized as containment (Bryant 2017).

There is always tension between that part of the national population which is resistant to migrant and refugee arrivals, and that part which sees the humanitarian need of others, and has the desire to profile their nation as open and humanitarian in nature. The level of public interest in assisting refugees has increased, and strengthened over recent years, even as the other extreme has been more vocal. The increase in public interest in supporting refugees is perhaps particularly pronounced as high numbers of Syrians have been displaced by conflict since 2011 and 'Welcome' movements of various sorts began in different European countries. Several civil society organizations, such as Citizens UK, pressured the UK government to allow local, civil society groups to play a greater role in assistance programs. This pressure started in around 2014, and in October 2015 the government 
announced it would investigate the possibilities for Community Sponsorship. The scheme was launched in 2016, with a first refugee family being welcomed in Manchester in November 2016. By the end of 2018, more than 200 refugees had arrived in the UK, sponsored by some 140 groups (Sponsor Refugees 2019). These sponsored places did not add to the total anticipated arrivals on the programs, but may have contributed to the expansion to refugees of different nationalities impacted by the Syrian conflict, allowing the arrival of mixed nationality families (ERN+ 2017 scoping sponsorship).

Although the potential for sponsorship had been present from the start of the Gateway Program, with evidence tabled in Home Office conferences and reports reflecting on the Canadian experience with this approach, in particular, it required pressure from would be sponsors for the approach to be adopted (see van Selm 2003; Gelsthorpe 2003), largely mirroring the initial establishment of private sponsorship in Canada for the Indo-Chinese in 1979 (CCR 2014).

Interest in sponsorship is broadly based on a range of humanitarian, humanist, cultural and faith-based values. The motives for sponsorship in the UK, noted by Sponsor Refugees are (Sponsor Refugees 2019):

- It is a practical way for local people to respond to the global refugee crisis

- It provides a safe and legal route for refugees to come to the UK

- It makes maximum use of the capacity, commitment and networks of citizens to help refugees

- It improves the chances of refugees to settle in, learn English and find work

- It strengthens community bonds

- It sends a strong message that refugees are welcome in the UK.

Community sponsorship in the UK has been significantly inspired by the long-term success of private sponsorship of refugees in Canada, and supported in various ways by the Global Refugee Sponsorship Initiative (GRSI) set up by the Government of Canada, University of Ottawa, UNHCR, Giustra Foundation, and Open Society Foundation (GRSI 2019).

The total number of active sponsors remains relatively small compared to the total UK population, yet the small and quite recent programs are being positively reviewed by participants and observers. In particular, the facilitation of early integration and independence within local communities is being lauded in early evaluations of the community sponsorship approach (Alraie et al. 2018).

For the purposes of this chapter, the focus is on civil society actors as representative of particular norms and values in national society, and as connectors between refugees and broader society, as well as between governments (national and local) and populations, including the refugees. The role of civil society actors (both established taking on a new role, and new 
organizations formed for the purpose of sponsoring refugees) in community sponsorship is primarily that of facilitator - a prime example of the shifting trends in civil society's place in local and national processes (World Economic Forum 2013).

\section{Conceptualizing community sponsorship: values in action}

One way to try to understand the values at work in community sponsorship is to ask the simple question 'Why does someone want to sponsor refugees?' Refugee integration, particularly in a welfare state context in the UK, is generally thought to be the responsibility of governments, both national and local. What makes individuals or groups decide or suggest that they could sponsor refugee newcomers?

One category of answer would be in the personal realm: the refugee or family to be sponsored are related to, or known to, those sponsoring them. In some sponsorship situations in Canada, for example, the sponsored refugee can be identified by the private sponsors - and might be a relative of the sponsor, or of someone already in their community. In that case, "Why sponsor?' might be relatively easily answered as it is a direct way to assist a known individual or family.

However, in the UK, the refugees who are recipients of community sponsorship are identified by the government in collaboration with UNHCR (similar to the Blended Visa-Office Referred Program in Canada). The person or family being sponsored is therefore unknown to the sponsors and they are randomly matched. The reason to sponsor refugees is therefore based on broader, humanitarian values.

Another category of answer would be to expand programs by putting in financial or in-kind support (e.g. housing) for more refugee arrivals than those for whom the government has said it is prepared to pay. Sponsors, in the UK context, commit to provide housing for the first two years in terms of managing the relationship between the refugee tenant and the private landlord. The housing is actually paid for through housing benefits, however, and the actual financial commitment of the sponsors is relatively limited. Furthermore, sponsored refugees have been part of the overall caseload, not an addition to it, although changes to the UK resettlement program announced on June 18, 2019 mean that sponsorship places will, as of 2020 , be over and above the government program numbers (UK government 2019).

Indeed, the main role of sponsors in the UK is that of facilitators - a bridge offering guidance as well as some material assistance in the earliest days, and in some ways mentors, with a changing relationship over the course of time, as the refugees start to both integrate in wider society and become increasingly independent. Sponsors must be registered charities, and have permission from their local authorities to engage with the refugees, who will be housed in proximity to their sponsoring organization (ERN+2017). 
A third category of answer to the question 'Why sponsor' could be more pertinent, namely as an expression of commitment, values, and, in essences, of political approach to the thorny issues of immigration and protection. Perhaps the strongest underlying motives for sponsorship in the UK are involvement, and the expression of support for refugee arrivals - an expression which may be targeted not only at the refugees, but also at the UK government and at those people in society who oppose refugee arrivals, and/ or engage in far right and racist politics.

One recognized sponsorship organization, Migrants Organize, based in London says on their website:

One of the core benefits we see with community sponsorship is how it creates a strong network of allies, friends and neighbors to support newly arrived refugees who would otherwise be marginalized and isolated - from simple things like helping the family register with the GP and navigate public transport, to being a friendly face to chat with over a coffee. It is about having a community network invested in supporting them toward independence and to break down the loneliness and isolation often experienced by newly arrived refugees.

(Migrants Organize 2019)

Of the values claimed to be British values, the key elements here seem to be individual freedom (the liberty to choose to assist a newcomer, and the freedom of that individual or family to accept that help, or indicate where they are ready to do certain things alone), and tolerance. The toleration of newcomers, of their diversity, of their difficulties in adjusting, and of the whole group of helpers is key to making a success of the sponsorship, and central among the values being upheld through deeds and passed on to those receiving the assistance.

In setting out the Community Sponsorship Program, the government referred to $\mathrm{UK}$ values (using that term, not British values) only to explain that opposition to those values, or tolerance of such opposition, would be reason for refusing an organization the right or opportunity to sponsor refugees (UK Government 2018):

If we consider that your organization or the lead sponsor are not fit and proper to assume the responsibility of resettling a vulnerable family, we may refuse your application or revoke your approval. Reasons for this include, but are not limited to: the provision of false or inaccurate information; vocal or active opposition to fundamental UK values (or tolerance of such opposition) including democracy, the rule of law, individual liberty, universal human rights, gender equality, equality of opportunity, mutual respect and tolerance of different faiths and beliefs, freedom of speech; criminal convictions; immigration offences; or other illegal activity. 
Those organizations that have sponsored refugees are primarily faith-based (Christian) or part of the Refugees Welcome movement, and are following through on their strongly held values (Howden 2016). One question is whether their actions can help spread those values, and particularly tolerance, more deeply across the British population.

\section{Spreading values}

Actions speak louder than words: the expression of values among the community supporting refugees might fly largely under the radar of the wider population, particularly in larger city context, but the action of showing support, is known to the individual refugees and families concerned as well as among the sponsoring community. By requiring groups, NGOs, churches, and others to be broad, registered, and established, the British sponsorship model is essentially requiring both a basic standard and duty of care, and that it is a community, not just one or two individuals, that assists the refugee. The effect of this is to make sponsorship a kind of social gathering place, of community activity. The Church of England, reporting on the impact of sponsorship, says:

The astonishing fact of Community Sponsorship is that it works in any community, large or small, urban or rural. Recent figures published by the Home Office show that the region with the highest number of schemes is the rural South West. A family resettled in Ottery St Mary decided to call their baby daughter Mary in recognition of the friendship and support they have received from the community. The last two years have shown that an increasing number of communities are getting involved. In so doing they have discovered that helping to transform the lives of a resettled family, they have transformed their community for the better in the process, with greater communication, cohesion, and integration.

(Church of England 2019)

In other words, the act of sponsorship is not only an expression of values, but also a strengthening and spreading of those values within and beyond the group directly involved. Indeed, sponsorship brings opportunities to those who sponsor as well as to those they assist

Community sponsorship is a big commitment for any community group but has benefits beyond assisting newcomers to resettle; it offers communities the opportunity to flourish and brings them closer together through active participation and engagement with diversity.

(Alraie et al. 2018: 1)

Research on resettlement to the UK, not necessarily focused on sponsorship, shows that having support from the community, having connections, 
mentors, and guides to assist in the process, is a positive aspect in advancing the integration process (Collyer et al. 2019: 8). It facilitates other aspects of the integration path, such as access to education, learning the language, finding safe, secure, and stable housing.

As such, it is clear that the early findings on experience with Community Sponsorship in the UK find not only positives in the opportunities for integration of the refugees who are sponsored, but also a strengthening and spread of those values labelled 'British,' including tolerance and appreciation of diversity of all kinds.

\section{Tolerance - in short supply in a changing context?}

In his 1997 collection 'On Toleration,' which started as a series of lectures in Yale's Program in Ethics, Politics and Economics, Michael Walzer discusses tolerating and being tolerated as 'the work of democratic citizens,' work which is neither 'easy or insignificant' (Walzer 1997: xi).

Tolerance, as described in the policy papers on British values is about differences - specifically those in faith. Defending toleration, Walzer says, does not have to mean defending difference, although it often does. 'Toleration makes difference possible; difference makes toleration necessary' (Walzer 1997: xii).

Toleration is essentially about peaceful co-existence built on some form of mutual respect and acceptance. There are differences, therefore, following Walzer, we need toleration. Where immigration is concerned, however, a fundamental issue arises. Those who do not wish to tolerate see the answer as keeping out the differences by keeping out the migrants. The differences migrants bring (adding to differences already present) require toleration - in trying to reject those differences by rejecting the migrants, those who would oppose their arrival enter a spiral. The British value of tolerance is sorely tested by their intolerance.

Walzer identifies five 'regimes of toleration,' or models for a tolerant society: multinational Empires, International Society, Consociations, NationStates and Immigrant Societies. Great Britain has perhaps been through some of these, but is having difficulties with the last. Arguably, the British value of tolerance would have been grounded in its days of Empire - for all the prejudice and endemic corruption of the regime, the Imperial power may have been more even-handed towards ruling than any local prince or tyrant, as Walzer suggests. Post-empire as a variant on the 'consociation' of a United Kingdom of four parts, or as a nation-state (which various British citizens and governments may have viewed differently over time), the UK has had another regime of toleration broadly speaking at home.

However, where the UK struggles is with the consequences of Empire, the immigration of Commonwealth citizens with status and rights based on the changing relationship between their (newly) independent states and the UK, and the immigration of others, including EU citizens in the more recent 
regional/supra-national 'consociation.' Walzer treats France, and the 'European Community' as complicated cases. The Immigrant Societies in Walzer's theorizing on toleration are Canada, the US, and Australia. France is complicated because it is a nation-state that has accepted and assimilated a high-degree of its own colonial immigration pre- and post-independence of those states to which its imperial power spread.

The UK's difficulties with its essential value of tolerance in the first two decades of the 2000s may come from its changing nature as a society. Those for whom the values are central can tolerate, and show not only tolerance of but also support to a wider range of 'others' than those that Britain already contains. Those for whom the nation, Britain, is central, can espouse tolerance of others who are British, but a little different, but have difficulties extending tolerance to others arriving in the UK. The UK has become a very complicated case, where tolerance is espoused, but toleration not shown by all.

Those who represent the value (British or otherwise) of toleration by forming community organizations to support resettled refugees through sponsorship, uphold their country in its fundamental ability to tolerate difference and survive.

\section{Conclusion}

This chapter set out to present thoughts on the connections between British values, immigration and refugee protection, and through the prism of community sponsorship to comment on the nature of tolerance in a changing UK society and political nation.

The overwhelming sense to emerge is that there is a broad base of tolerance for difference in Britain, even if it is being sorely tested by the question of how much intolerance can be accepted. Walzer points out that tolerating the intolerant is not such a thorny issue as it is often portrayed to be. Some key aspects, from a political perspective, he says, are separating church and state, and separating politics from the state. Community sponsorship, if understood in part as taking on the government's job of working to integrate refugees in society, practiced primarily by faith-based organizations might be on tricky ground in terms of separating church and state, although clearly not all sponsors are faith-based and they are not, strictly speaking doing the state's job, but society's.

Separating politics from the state is a much more problematic proposition in today's Britain, where the continued existence of the state, and its international and regional political associations and trading arrangements are subject to entirely political decisions - but that goes beyond the realms of this chapter.

Returning to the three questions posed in introducing the chapter: how can we conceptualize participation in community sponsorship efforts from a values perspective? How could sponsorship of refugees by a few spread those values to, or strengthen those values in others in society? How can tolerance 
be understood, and developed, in a country where immigration has happened more quickly than its core citizenry has managed to adapt to it?

The discussion set out above has shown that conceptualizing participation in community sponsorship from a values perspective rests largely, but not exclusively, on tolerance. Sponsors set out from the desire to ensure a smooth path to both integration and independence on the part of refugees for whom they feel a deep sense of humanitarian empathy. Their values might, quite quietly and on a step by step basis, spread to others in society, although the fissures in the UK run deep at this juncture. A major reason for those fissures is that a significant part of the British population has not been prepared, or is not ready, for the changes in immigration that recent decades have brought. The problematic approach to values and their connection to immigration and refugee protection, as to broader political issues in the UK today, are deeply rooted in the transition from Empire to participant in a regional political and economic regime designed to bring peace and stability. Understanding and resolving those issues goes far beyond this study, but reflecting on approaches such as sponsorship, which promotes human interaction, understanding and tolerance, is one way to start addressing these problems through practical measures.

\section{References}

Alraie, M., Collins, H., \& Rigon, A., in partnership with Citizens UK (2018). A Comparison of Community Sponsorship and Government-Led Resettlement of Refugees in the UK: Perspectives from Newcomers and Host Communities. September 2018. Available at: www.ucl.ac.uk/bartlett/development/sites/bartlett/files/comparisonukreset tlement_schemes_fullreport.pdf

Ballinger, S. (2018). Many Rivers Crossed: Britain's Attitude to Race and Integration 50 Years since 'Rivers of Blood'. Available at: www.britishfuture.org/wp-content/uploa ds/2018/04/ManyRiversCrossed2.pdf

Blinder, S. \& Richards, L. (2018). UK Public Opinion towards Immigration: Overall Attitudes and Level of Concern, Migration Observatory. June 2018. Available at: http s://migrationobservatory.ox.ac.uk/resources/briefings/uk-public-opinion-towa rd-immigration-overall-attitudes-and-level-of-concern/

Bryant, J. (2017). The UK and Humanitarian Reform: In Whose Interest? Available at: www.odi.org/blogs/10567-uk-and-humanitarian-reform-whose-interest

CCR (Canadian Council for Refugees) (2014). Canada's Private Sponsorship of Refugees Program: Proud History, Uncertain Future. Available at: https:/ccrweb.ca/sites/ ccrweb.ca/files/psr-overview-challenges.pdf. https:/ccrweb.ca/sites/ccrweb.ca/files/p sr-overview-challenges.pdf" https://ccrweb.ca/sites/ccrweb.ca/files/psr-overview-cha llenges.pdf

Church of England (2019). How Community Sponsorship is Transforming Lives. 11 January 2019. Available at: www.churchofengland.org/more/media-centre/stories-a nd-features/how-community-sponsorship-transforming-lives

Collyer, M. et al. (2019). A Long-Term Commitment: Integration of Resettled Refugees in the UK. University of Sussex. Available at: www.sussex.ac.uk/webteam/gateway/ file.php?name $=4375$-resettled-refugees-report-web.pdf\& site $=252$ 
ERN+ (2017). Private Sponsorship in Europe. Available at: www.resettlement.eu/sites/ icmc/files/ERN\%2B\%20Private\%20Sponsorship \%20in \%20Europe \%20-\%20Expa nding $\% 20$ complementary $\% 20$ pathways $\% 20$ for $\% 20$ refugee $\% 20$ resettlement.pdf

ERN+ (2018). Feasibility Studies on Humanitarian Admission Programmes, Private Sponsorship and Higher Education Scholarships for Refugees. Available at: www.resettlement. eu/page/ern-publications. www.icmc.net/sites/default/files/documents/scoping-paper-icm c-europe-2017.pdf

Gelsthorpe, V. \& Herlitz, L. (2003). Listening to the Evidence: The Future of UK Resettlement. London: Home Office. Available at: https://webarchive.nationalarchives. gov.uk/20080205190743/www.homeoffice.gov.uk/rds/pdfs2/resettlement.pdf

GRSI (2019). Community Sponsoring. Available at: http://refugeesponsorship.org/comm unity-sponsorship

Guild, E. (2000). 'The United Kingdom: Kosovar Albanian Refugees,' in van Selm, J. (ed.), Kosovo's Refugees in the European Union. London: Continuum, pp. 67-90.

Howden, D. (2016). 'Why Britain chose to partially privatize refugee resettlement,' Refugees Deeply, 3 August. Available at: www.newsdeeply.com/refugees/comm unity/2016/08/03/why-britain-chose-to-partially-privatize-refugee-resettlement

Jarvis, L., Atakav, E., \& Marsden, L. (2017). 'What British Muslims think about the term "British Values", The Conversation, 30 October. Available at: https:/the conversation.com/what-british-muslims-think-about-the-term-british-values-86423

Migrants Organize (2019). We're Becoming Community Sponsors - You Can Too. Available at: www.migrantsorganise.org/? $\mathrm{p}=27545$

Richardson, R. (2015). 'British values and British identity: Muddles, mixtures, and ways ahead,' London Review of Education 13(2), pp. 37-48.

Rutter, J. et al. (2018). National Conversation on Immigration: Final Report. Available at: www.britishfuture.org/wp-content/uploads/2018/09/Final-report.National-Conversa tion.17.9.18.pdf

Selm, J., van. (2003). 'Lessons on resettlement from the US and Canada,' in Gelsthorpe, V. \& Herlitz, L. (eds) Listening to the Evidence: The Future of UK Resettlement. London: Home Office, pp. 33-43.

Sponsor Refugees (2019). Welcome. Available at: www.sponsorrefugees.org

UK Government (2011). Prevent Strategy. Available at: https://assets.publishing.service. gov.uk/government/uploads/system/uploads/attachment_data/file/97976/preventstrategy-review.pdf

UK Government (2016a). Gateway Protection Programme. Available at: www.gov.uk/hm rc-internal-manuals/tax-credits-manual/tcm0290170

UK Government (2016b). New Scheme Launched to Resettle Children at Risk. Available at: www.gov.uk/government/news/new-scheme-launched-to-resettle-children-at-risk

UK Government (2017). Syrian Vulnerable Persons Resettlement Scheme: Guidance for Local Authorities and Partners. Available at: https://assets.publishing.service.gov.uk/ government/uploads/system/uploads/attachment_data/file/631369/170711_Syrian_ Resettlement_Updated_Fact_Sheet_final.pdf

UK Government (2018). Guidance for Prospective Sponsors (first published July 2016, updated December 2018). Available at: https://assets.publishing.service.gov.uk/gov ernment/uploads/system/uploads/attachment_data/file/764990/2018-12-04_Comm unity_Sponsorship_Guidance.pdf

UK Government (2019). New Global Resettlement Scheme for the Most Vulnerable Refugees Announced. Available at: www.gov.uk/government/news/new-global-resettlem ent-scheme-for-the-most-vulnerable-refugees-announced 


\section{J. van Selm}

Walzer, M. (1997). On Toleration. Yale University Press: New Haven

World Economic Forum (2013). The Future Role of Civil Society. Available at: www3. weforum.org/docs/WEF_FutureRoleCivilSociety_Report_2013.pdf

Yates, K. (2016). "How the E.U. referendum exposed how toxic "British Values" really are,' The Fader. Available at: www.thefader.com/2016/06/30/eu-referendum -britsh-values-essay 